\title{
Fabrication and Characterization of Mullite Reinforced MgO Added $\mathrm{ZrO}_{2}$ Ceramics
}

\author{
Mehmet Akif Hafizoğlu ${ }^{1 *}$, Tahsin Boyraz ${ }^{2}$, Ahmet Akkuş ${ }^{3}$ \\ ${ }^{1 *}$ Sivas Cumhuriyet University, Faculty of Engineering, Department of Mechanical Engineering, Sivas, Turkey, (ORCID: 0000-0002-9689-3004), \\ mehmedhaf@hotmail.com \\ ${ }^{2}$ Sivas Cumhuriyet University, Faculty of Engineering, Department of Metallurgical and Materials Engineering, Sivas, Turkey, (ORCID: 0000-0003-4404-6388), \\ tahsinboyraz@cumhuriyet.edu.tr \\ ${ }^{3}$ Sivas Cumhuriyet University, Faculty of Engineering, Department of Mechanical Engineering, Sivas, Turkey, (ORCID: 0000-0002-6881-9333), \\ aakkus@cumhuriyet.edu.tr
}

(1st International Conference on Applied Engineering and Natural Sciences ICAENS 2021, November 1-3, 2021)

(DOI: 10.31590/ejosat.1013063)

ATIF/REFERENCE: Hafizoğlu, M. A., Boyraz, T. \& Akkuş, A. (2021). Fabrication and Characterization of Mullite Reinforced MgO Added $\mathrm{ZrO}_{2}$ Ceramics. European Journal of Science and Technology, (28), 1197-1203.

\begin{abstract}
In this study, mullite $\left(3 \mathrm{Al}_{2} \mathrm{O}_{3} .2 \mathrm{SiO}_{2}\right)$ and $10 \mathrm{~mol} \%$ magnesia added zirconia $\left(10 \mathrm{~mol} \% \mathrm{MgO}-90 \mathrm{~mol} \% \mathrm{ZrO}_{2}\right)$ ceramic powders were synthesized by conventional ceramic production processing route. The mixtures were prepared by mechanical alloying method in acetone environment with zirconia ball mill. The powders were dried in oven at $110^{\circ} \mathrm{C}$ for 24 hours before mixing. Mullite $\left(3 \mathrm{Al}_{2} \mathrm{O}_{3} .2 \mathrm{SiO}_{2}\right)$ and $10 \mathrm{~mol} \%$ magnesia added zirconia $\left(\mathrm{MgO}-\mathrm{ZrO}_{2}\right)$ ceramic powders were synthesized by reaction sintering from the powders made up of stoichiometric proportions of $\mathrm{Al}_{2} \mathrm{O}_{3}, \mathrm{SiO}_{2}, \mathrm{MgO}$ and $\mathrm{ZrO}_{2}$ powders after being homogenized in acetone environment in ball mills. Mullite $\left(3 \mathrm{Al}_{2} \mathrm{O}_{3} \cdot 2 \mathrm{SiO}_{2}\right)$ and $10 \mathrm{~mol} \%$ magnesia added zirconia $\left.(\mathrm{MgO}-\mathrm{ZrO})_{2}\right)$ ceramic powders were synthesized in air at $1600{ }^{\circ} \mathrm{C}$ for $3 \mathrm{~h}$ and $1300{ }^{\circ} \mathrm{C}$ for $2 \mathrm{~h}$, respectively. Then, the ceramic phases formed were made ready to form ceramic - ceramic composites by crushing, grinding and sieving processes. Then 0 and $10 \%$ by weight mullite (M) added magnesia doped zirconia (MgZ) mixtures were prepared by powder metallurgy method. The prepared mixtures were wet milled with zirconia ball mill for $24 \mathrm{~h}$ and sieved. After drying, the powders were compacted to preforms of $56 \times 12 \times 10 \mathrm{~mm}$ by uniaxial pressing at $200 \mathrm{MPa}$. The green compacts were sintered at $1500-1600{ }^{\circ} \mathrm{C}$ for $1-5 \mathrm{~h}$ in air conditions using a heating rate of $5{ }^{\circ} \mathrm{C}$ min- 1 in a high temperature furnace. Then, microstructure (SEM), phase analysis (XRD), mechanical (hardness, 3-point bending and wear) and physical properties (\% shrinkage, water absorption, porosity and density) tests were performed on the mullite added magnesia doped zirconia ceramic composites. In this study, whether there is a phase change in the $\mathrm{ZrO}_{2}-\mathrm{MgO}$ mixture at high sintering temperatures and the effect of mullite additive on the properties of this mixture was investigated. The data obtained were presented in graphs and tables and their comments were made.
\end{abstract}

Keywords: Zirconia, Mullite, Magnesia, Characterization, Wear.

\section{Mullit Takviyeli MgO Katkılı $\mathrm{ZrO}_{2}$ Seramiklerinin İmalatı ve Karakterizasyonu}

$\ddot{O} \mathbf{z}$

Bu çalışmada, mullit $\left(3 \mathrm{Al}_{2} \mathrm{O}_{3} \cdot 2 \mathrm{SiO}_{2}\right)$ ve $\% 10 \mathrm{~mol}$ magnezya katkılı zirkonya ( $\% 10 \mathrm{~mol} \mathrm{MgO} \mathrm{-} \% 90$ mol $\left.\mathrm{ZrO}_{2}\right)$ seramik tozları geleneksel seramik üretim yöntemi ile sentezlenmiştir. Karışımlar, zirkonya bilyalı değirmende aseton ortamında mekanik alaşımlama yöntemiyle hazırlanmıştır. Tozlar karıştırılmadan önce $110^{\circ} \mathrm{C}$ 'de 24 saat etüvde kurutulmuştur. $\mathrm{Al}_{2} \mathrm{O}_{3}, \mathrm{SiO}_{2}, \mathrm{MgO}$ ve $\mathrm{ZrO}_{2}$ tozlarının stokiyometrik oranlarından oluşan tozların aseton ortamında bilyeli değirmende homojenize edildikten sonra geleneksel sinterleme yöntemiyle Mullit $\left(3 \mathrm{Al}_{2} \mathrm{O}_{3} \cdot 2 \mathrm{SiO}_{2}\right)$ ve $\% 10 \mathrm{~mol}$ magnezya katkılı zirkonya $\left(\mathrm{MgO}-\mathrm{ZrO}_{2}\right)$ seramik tozları sentezlenmiştir. Mullit ve \%10 mol magnezya katkılı zirkonya seramik tozları sırasıyla $1600^{\circ} \mathrm{C}$ 'de 3 saat ve $1300^{\circ} \mathrm{C}$ 'de 2 saat sentezlenmiştir. Daha sonra oluşan seramik fazlar kırma, ögütme ve eleme işlemleri ile seramik - seramik kompozitleri oluşturmaya hazır hale getirilmiştir. Daha sonra ağırlıça \%0 ve \%10 mullit (M) takviyeli magnezya katkılı zirkonya (MgZ) karışımları toz metalurjisi yöntemiyle hazırlanmıştır. Hazırlanan karışımlar zirkonya bilyalı değirmende 24 saat yaş öğütülmüş ve elenmiştir. Kurutulduktan sonra, tozlar $200 \mathrm{MPa}$ 'da tek eksenli presleme ile 56x12x10 mm'lik preformlara sıkıştırılmıştır. Devamında, yüksek sıcaklıklı bir firında $5{ }^{\circ} \mathrm{C} /$ dak 1 sıtma hızı kullanılarak hava koşullarında 1500-1600 oC'de 1-5 saat sinterlenmiştir. Daha sonra mullit takviyeli magnezya katkılı zirkonya seramik kompozitler üzerinde mikroyapı (SEM), faz analizi (XRD), mekanik (sertlik, 3 nokta eğme ve aşınma) ve fiziksel özellikler (\% küçülme, su emme, gözeneklilik ve yoğunluk) testleri yapılmıştır. Bu çalışmada, yüksek sinterleme sıcaklıklarında $\mathrm{ZrO}_{2}-\mathrm{MgO}_{\mathrm{gar}}$ şımında faz değişimi

* Corresponding Author: mehmedhaf@hotmail.com 
olup olmadığı ve mullit katkı maddesinin bu karışımın özelliklerine etkisi araştırılmıştı. Elde edilen veriler grafik ve tablolar halinde sunulmuş ve yorumları yapılmıştır.

Anahtar Kelimeler: Zirkonya, Mullit, Magnezya, Karakterizasyon, Aşınma.

\section{Introduction}

Ceramic materials as a high temperature structural material due to their several interesting features such as, excellent resistance to heat, corrosion and abrasion, are preferred, in numerous areas like, cutting tools, extrusion dies, adiabatic diesel engine compartments [1-3]. However, ceramic materials have many disadvantages, such as low impact strength and fracture toughness, fragility and limited processability. So, a lot of studies focus on these issues to improve the structural and mechanical properties of ceramics. Among ceramic materials, zirconia $\left(\mathrm{ZrO}_{2}\right)$ and its composites have recently become the focus of scientific and technological studies because of their better mechanical properties, corrosion resistance, high temperature stability, low thermal conductivity and high chemical stability. [1]. They are used as structural materials in the manufacture of refractory crucibles for melting pure metals, components of furnaces, engines, heat barriers, wear resistant components, blade cutting tools and wire mesh drawing machines, dental studies and other a lot of fields [1-4]. High-purity zirconia $\left(\mathrm{ZrO}_{2}\right)$ exhibits three polymorphs depending on temperature: monoclinic phase is stable up to about $1170^{\circ} \mathrm{C}$. After this temperature, the conversion from the monoclinic phase to the tetragonal phase begins and the tetragonal phase is stable up to $2370^{\circ} \mathrm{C}$. From this temperature to the melting temperature of $2680{ }^{\circ} \mathrm{C}$, it is in the cubic phase. [1,4]. During the cooling process, transition from the tetragonal to monoclinic phase occurs. This transformation is very important because of resulting in a volumetric change of around 3\% to $5 \%$ and so, leads to cracks. To prevent this transformation and stabilize the zirconia, it is common to use stabilizers. The addition of stabilizers to $\mathrm{ZrO}_{2}$, lowers the temperature of polymorphic transformations, reduces the volume changes and blocks the transformation. With using stabilizers, it is possible to ensure the existence of high-temperature phases at room temperature too [4]. Different stabilizers, such as, $\mathrm{Al}_{2} \mathrm{O}_{3}, \mathrm{CaO}, \mathrm{CeO}_{2}, \mathrm{MgO}, \mathrm{SiO}_{2}$, $\mathrm{TiO}_{2}, \mathrm{Y}_{2} \mathrm{O}_{3}$ and even a combination of them, stabilize and keep stable the $\mathrm{ZrO}_{2}$ in the tetragonal and/or cubic forms at room temperature [5-7]. It is possible to produce materials consisting of only $\mathrm{t}-\mathrm{ZrO}_{2}$ or c- $\mathrm{ZrO}_{2}$ or a mixture of these with $\mathrm{m}-\mathrm{ZrO}_{2}$ phases by adding different quantities of stabilizer. If less than sufficient stabilizing oxide is added, partially stabilized zirconia (PSZ) is obtained instead of fully stabilized zirconia. PSZ usually consists of two or more closely mixed phases. As a result of using stabilizers and obtaining fully or partially stabilized zirconia, achieve excellent mechanical properties such as bending strength, fracture toughness, hardness [8].

Although, zirconia exhibits better mechanical properties than other ceramics, but like all other ceramics, it is fragile and cannot be formed at room temperature. So, we want to increase the toughness of these materials. For this, some energy absorbing mechanisms such as transformation toughening and fiber reinforcement are used in ceramic matrices [1].

In the method of increasing fracture toughness with transformation toughness, it works on the principle of a phase transformation caused by tension, by reducing the driving force that propagates existing cracks in the material structure [1]. The best example of this is zirconia. Zirconia which is added to the ceramic main phase, plays an important role in increasing the fracture toughness and thus the bending strength with its tetragonal - monoclinic transformation toughening feature. With the discovery of the transformation toughening that occurs in zirconia, this material has found wide use. Because the main factor limiting the use of $\mathrm{ZrO}_{2}$ in advanced engineering applications was the low toughness of this material. Increasing the toughness property with transformation toughness has also increased the interest in zirconia. The volume increase of $3-5 \%$, which occurs with the tetragonal - monoclinic phase transformation in zirconia, prevents crack propagation and increases the toughness of the material and its resistance to fracture [9]. The $t-m$ transformation in zirconia can occur in different ways. For example: $\mathrm{t}-\mathrm{ZrO}_{2}$ can be free as a single particle or crystal; It can also be found in a compacted form in a matrix as a precipitate phase. Tetragonal zirconia particle size and the matrix in which the particles are compacted are the most important factors. A critical $\mathrm{t}-\mathrm{ZrO}_{2}$ grain size determine in $\mathrm{ZrO}_{2}$. If the grain size is below this critical size, there will be no transformation; above, the t-m transformation occurs either continuously or as a result of applying a stress [10].

In the ceramic - ceramic mixed structure formation process, which is the other method of increasing the fracture toughness, the strength and toughness are increased by adding ceramic whiskers, fibers or particles to the main phase. This method is based on creating a physical barrier to the progressive crack. Having higher tensile strength than polycrystalline material, whiskers are a good barrier to propagation cracking. So, the fracture toughness of the submicrometric or nanocrystalline zirconia can be further increased by adding secondary phases into zirconia matrix, such as nanotubes, nanofibres or nanoplatelets [11]. During the last decades, the development of nanomaterials has offered a new alternative for reinforcing ceramics. Carbon nanotubes (CNTs) have attracted increasing attention as reinforcement because of their excellent properties. However, the $\mathrm{CNTs}$ are prone to reacting with an oxide matrix at high temperature, leading to the degradation in mechanical properties of CNTs and a limited reinforcing effect on the ceramics $[12,13]$. So, it is stated that incorporation of mullite which is another type of ceramic toughening method with its high temperature oxidation and corrosion resistance and the other superior properties, might be preferred [11]. In the literature, mullite $\left(3 \mathrm{Al}_{2} \mathrm{O}_{3} \cdot 2 \mathrm{SiO}_{2}\right)$ is defined as the unique stable intermediate crystalline phase of the $\mathrm{Al}_{2} \mathrm{O}_{3}-\mathrm{SiO}_{2}$ binary system, cost-friendly and exhibiting good refractory ability $[14,15]$. Mullite has received significant attention for technological applications due to its good properties such as high melting point, low coefficient of thermal expansion, high chemical stability, high creep resistance and sufficient hardness $[16,17]$. In summary, the fracture toughness of the submicron or nanocrystalline zirconia can be further improved by adding mullite being the secondary phase into the zirconia matrix and so, the other mechanical properties can be improved too [11] In addition, the sintering temperature is also particularly important, because it affected the properties of ceramics through alteration of the microstructure and crystalline phases [18]. Studies continue on the effect of different sintering temperatures on the microstructure and mechanical properties of mullitezirconia ceramics. 
In this study, mullite $\left(3 \mathrm{Al}_{2} \mathrm{O}_{3} \cdot 2 \mathrm{SiO}_{2}\right)$ and $10 \mathrm{~mol} \%$ magnesia doped zirconia $\left(\mathrm{MgO}-\mathrm{ZrO}_{2}\right)$ ceramic powders were synthesized by conventional ceramic production processing route. Then, the effect of mullite additive on the properties of this mixture was investigated. The data obtained were presented in graphs and tables and their results were commented.

\section{Material and Method}

Mullite and magnesia doped zirconia ceramic powders were produced by conventional ceramic production processing route in this study. All precursory powder materials $\left(\mathrm{Al}_{2} \mathrm{O}_{3}, \mathrm{SiO}_{2}, \mathrm{MgO}\right.$ and $\mathrm{ZrO}_{2}$ ) used in the present work were purchased from Eczacibaşı Company, Alfa Aesar and Handan Yaxiang Chemicals Trading Co., Ltd (Eczacıbaşı Esan, Turkey; Alfa Aesar, United States of America and Handan Yaxiang Chemicals Trading Co., Ltd, China). The mixtures were prepared by mechanical alloying method in acetone environment with zirconia ball mill. The powders were dried in oven at $110^{\circ} \mathrm{C}$ for 24 hours before mixing. Mullite $\left(3 \mathrm{Al}_{2} \mathrm{O}_{3} \cdot 2 \mathrm{SiO}_{2}\right)$ and $10 \mathrm{~mol} \%$ magnesia doped zirconia $\left(\mathrm{MgO}-\mathrm{ZrO}_{2}\right)$ ceramic powders were synthesized by reaction sintering from the powders made up of stoichiometric proportions of $\mathrm{Al}_{2} \mathrm{O}_{3}, \mathrm{SiO}_{2}, \mathrm{MgO}$ and $\mathrm{ZrO}_{2}$ powders after being homogenized in acetone environment in ball mills. Mullite $\left(3 \mathrm{Al}_{2} \mathrm{O}_{3} \cdot 2 \mathrm{SiO}_{2}\right)$ and $10 \mathrm{~mol} \%$ magnesia doped zirconia $\left(\mathrm{MgO}-\mathrm{ZrO}_{2}\right)$ ceramic powders were synthesized in air at $1600{ }^{\circ} \mathrm{C}$ and $1300^{\circ} \mathrm{C}$ for $3 \mathrm{~h}$ and $2 \mathrm{~h}$, respectively. Then, the ceramic phases formed were made ready to form ceramic - ceramic composites by crushing, grinding and sieving processes. Then 0 and $10 \%$ by weight mullite added magnesia doped zirconia mixtures were prepared by powder metallurgy method (hereinafter these mixtures will be named MgZ0M and MgZ10M respectively). The sample was coded as MgZ10M16005 (MgZ: Magnesia doped zirconia; 10M: 10\% Mullite addition and 16005 : $1600{ }^{\circ} \mathrm{C}$ sintering temperature and 5 hours sintering time). The prepared mixtures were wet milled with zirconia ball mill for $24 \mathrm{~h}$ and sieved. After drying, the powders were compacted to preforms of $56 \times 12 \times 10 \mathrm{~mm}$ by uniaxial pressing at $200 \mathrm{MPa}$. The green compacts were sintered at 1500 $1600{ }^{\circ} \mathrm{C}$ for $1-5 \mathrm{~h}$ in air conditions using a heating rate of $5{ }^{\circ} \mathrm{C}$ $\mathrm{min}^{-1}$ in a high temperature furnace (Protherm ${ }^{\mathrm{TM}}$ Furnace). Then, microstructure (SEM), phase analysis (XRD), mechanical (hardness, 3-point bending and wear) and physical properties ( $\%$ shrinkage, water absorption, porosity and density) tests were performed on the mullite added magnesia doped zirconia ceramic composites.

The 3-point bending strength tests of the samples were performed on with a crosshead speed of $0.5 \mathrm{~mm} / \mathrm{min}$ in a Shimadzu brand tensile-compression device. Five measurements were made for each sample and average results were accepted as the strength values of the samples. The strength calculations were made with the formula:

$$
\sigma=3 / 2 * P^{*} L /\left(b^{*} h^{2}\right)
$$

(In (1) the letters mean that, P: maximum applied load, L: distance between supports, b: width, h: height).

The samples were polished on a velvet broadcloth using a 1 $\mu \mathrm{m}$ diamond solution after the 180, 320, 600, 1200 and 2500 grit sanding process, respectively. The diagonal field traces on the polished specimens were created using a square pyramid diamond tip with a $136^{\circ}$ apex angle and $1 \mathrm{~kg}$ load for 10 seconds on the Mitutoyo brand vickers hardness tester. When calculating the hardness values, five measurements were taken and the results were given as average [19-24]. Plint brand wear tester was used for the wear tests of ceramics. Steel discs were used as wear disc. Wear tests were performed on each sample at $400 \mathrm{rpm}$ rate, 5, 10 and $15 \mathrm{~min}$ wear durations and $100 \mathrm{~N}$ force. First, the specimen was measured with a precision scale of $0.0001 \mathrm{~g}$, and the amount of wear was determined by measuring again after the specified wear time $[22,23]$. To determine the phases, X-ray powder diffractometer with $\mathrm{Cu} \mathrm{K} \alpha$ radiation (Bruker AXS D8 Advance; $20 \mathrm{kV}-60 \mathrm{kV}, 6 \mathrm{~mA}-80 \mathrm{~mA}$ and $\theta=10^{\circ}-90^{\circ}, 0.002^{\circ}$ ) was used. The phase analysis of the XRD patterns was determined using the Pananalitical X'Pert High Score program. The microstructural characterization of the samples was made with the Mira3XMU FE-SEM (Tescan, Czech Republic) brand scanning electron microscope (SEM) with an energy dispersion spectrum (EDS). The data obtained were presented in graphs and tables and their comments were made.

\section{Results and Discussion}

Specified to sintered samples: Physical tests (total shrinkage, water absorption, porosity and density tests), mechanical tests (hardness, 3-point bending and wear), scanning electron microscopy (SEM) for EDS analysis and XRD for phase analysis. Measurements and calculations were made 5 times replicates, and their arithmetic averages were obtained.

Table 1. Physical test results of MgZOM and MgZ10M samples

\begin{tabular}{lccccc}
\hline Samples & $\begin{array}{c}\text { Bulk } \\
\text { dens. } \\
\text { g/cm }\end{array}$ & $\begin{array}{c}\text { Rel. } \\
\text { dens. } \\
\mathbf{( \% )}\end{array}$ & $\begin{array}{c}\text { Water } \\
\text { Absorp. } \\
\mathbf{( \% )}\end{array}$ & $\begin{array}{c}\text { Por. } \\
\mathbf{( \% )}\end{array}$ & $\begin{array}{c}\text { Shir. } \\
\mathbf{( \% )}\end{array}$ \\
\hline MgZ00M15001 & 5,35 & 95,77 & 0,56 & 4,23 & 13,45 \\
MgZ00M15005 & 5,47 & 97,95 & 0,51 & 2,05 & 14,15 \\
$M g Z 00 M 16001$ & 5,49 & 98,32 & 0,49 & 1,68 & 14,33 \\
$M g Z 00 M 16005$ & 5,55 & 99,39 & 0,41 & 0,61 & 14,42 \\
$M g Z 10 M 15001$ & 4,67 & 88,70 & 0,25 & 11,30 & 11,63 \\
$M g Z 10 M 15005$ & 4,76 & 90,51 & 0,14 & 9,49 & 12,08 \\
$M g Z 10 M 16001$ & 4,61 & 87,69 & 1,15 & 12,31 & 11,34 \\
$M g Z 10 M 16005$ & 4,62 & 87,71 & 1,13 & 12,29 & 11,59 \\
\hline
\end{tabular}

The results of physical measurements (water absorption, bulk density, porosity and shrinkage) are given in Table 1, and also shown Figure 1. In Figure 1, the relative density values were taken at the rate of $1 / 3$ of the actual values for the graph to be more understandable.

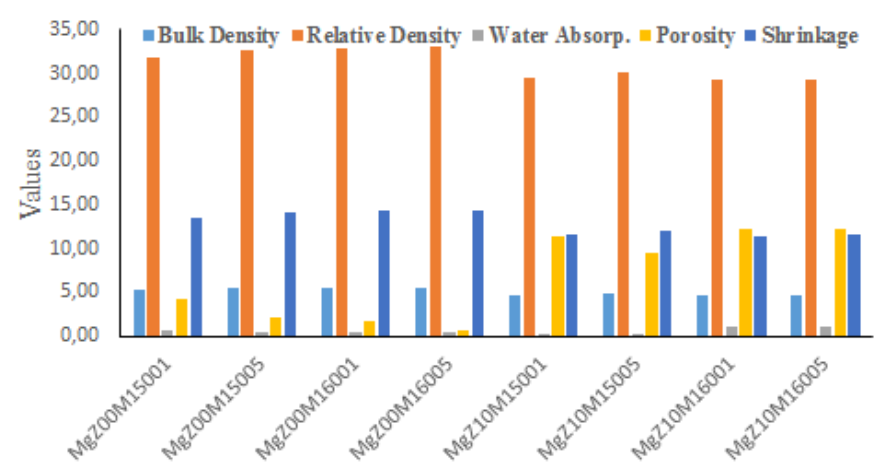

Figure 1. Physical test results graph of MgZOM and MgZ10M samples 
From the physical test results, it is seen that the shrinkage, experimental density and relative density values increase with increasing sintering temperature and time in mullite-free samples, and accordingly, the water absorption and porosity values decrease. In the mullite added samples, while the experimental density, relative density and shrinkage values increase in 1500 samples; these values decrease in 1600 samples. We think that this is a result of the defects and phase changes occurring in the microstructure at $1600{ }^{\circ} \mathrm{C}$ temperature. In addition, it is seen that the shrinkage, experimental density and relative density values are lower in mullite added samples, and the water absorption and porosity values are higher than the mullite-free samples.

Table 2, Figure 2 and Figure 3 indicated hardness and 3-point bending strength values of MgZ0M and MgZ10M samples.

From the Table 2 and Figure 2, when the hardness test results are examined, it is seen that the hardness values increased with increasing sintering temperature and time in mullite-free samples generally. But the hardness values of mullite added 1600 samples decreased with increasing the sintering temperature and time. We think that decreasing the hardness values in 1600 samples with mullite and 16005 without mullite, is related to the large pores formed in the microstructure and possible phase changes. In addition, it is seen that mullite additive reduces the hardness of the samples.

Table 2. Hardness and 3-point bending strength values of $\mathrm{MgZOM}$ and $\mathrm{MgZ10M}$ samples

\begin{tabular}{lcc}
\hline Samples & $\begin{array}{c}\text { Hardness } \\
\text { (HV) }\end{array}$ & $\begin{array}{c}\text { 3 - Point Bending } \\
\text { Strength (MPa) }\end{array}$ \\
\cline { 2 - 3 } MgZ00M15001 & 783,38 & 150,40 \\
MgZ00M15005 & 831,06 & 123,47 \\
MgZ00M16001 & 835,02 & 110,94 \\
MgZ00M16005 & 822,65 & 92,29 \\
MgZ10M15001 & 479,63 & 60,27 \\
MgZ10M15005 & 521,17 & 61,25 \\
MgZ10M16001 & 407,95 & 88,06 \\
MgZ10M16005 & 428,83 & 99,50 \\
\hline
\end{tabular}

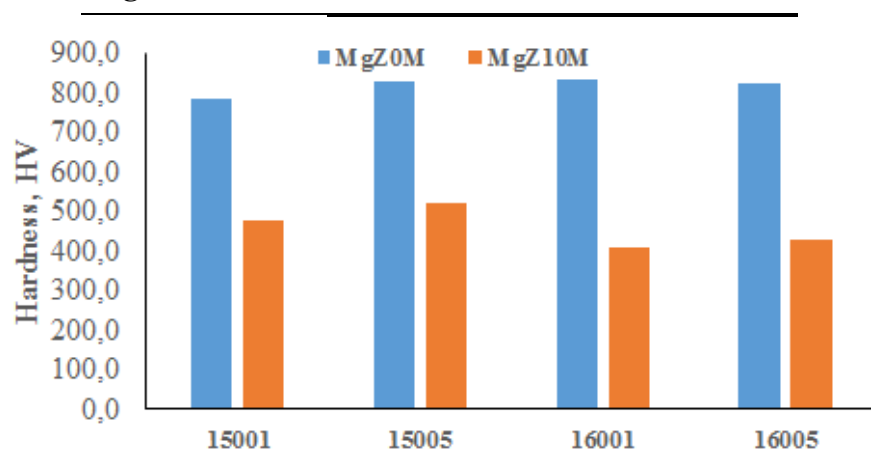

Figure 2. Hardness graph of samples

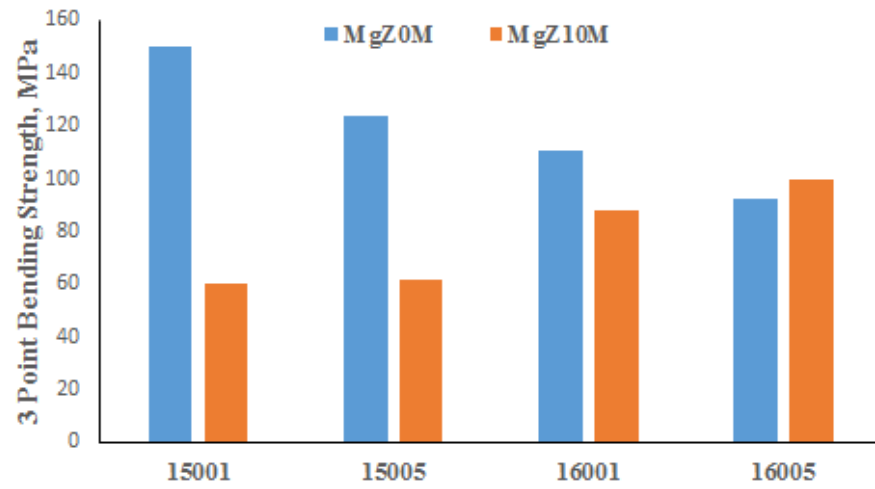

Figure 3. 3-Point bending strength graph of samples

The bending test results show that three - point bending strength values decreased with increasing sintering temperature and time in mullite-free samples; but in the mullite-added samples, on the contrary to the un-doped samples, the results show that the three-point bending strength values increased with increasing sintering temperature and time. Although the threepoint bending strength values of the mullite-added samples increase in direct proportion to the temperature and time, it is seen that they are still lower than the un-doped samples. We think that this is about the differences in the microstructure and possible phase changes depending on the sintering temperature, sintering time and mullite additive.

Plint brand wear tester was used for the wear tests of ceramics. Steel disc is used as wear disc. Wear tests were performed on each sample at 5,10 and 15 min wear durations and $100 \mathrm{~N}$ force (400 rpm constant speed). First, the specimen was measured with a precision scale of $0.0001 \mathrm{~g}$, and the amount of wear was determined by measuring again after the specified wear time. The wear results are shown in Table 3 and Figure 4.

Table 3. Wear Results of MgZOM and MgZ10M Samples

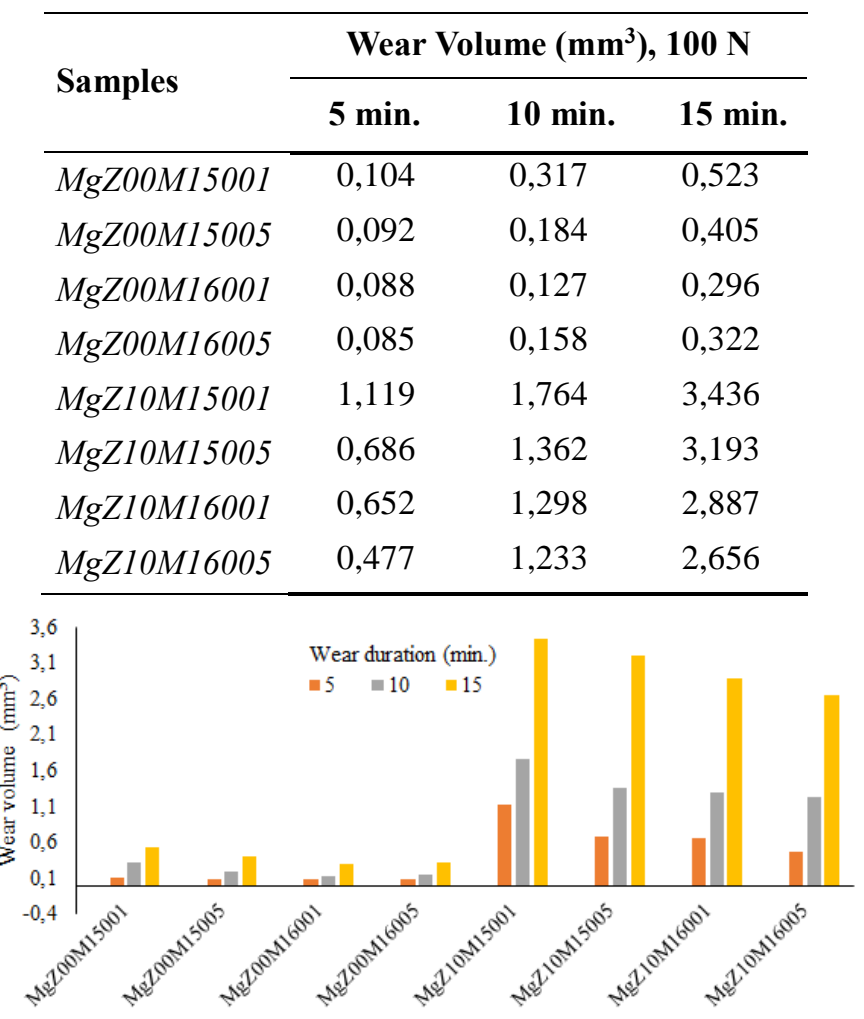

Figure 4. Wear test results graph of samples 
We see from the wear test results that, the results vary depending on the hardness, bending strength and wear time of the samples. In general, as the wear time increased, the amount of wear of the samples also increased. The wear resistance of the samples with high hardness and bending strength is higher and the mullite additive affected negatively and reduced the wear resistance of these samples.

For the mullite-added samples, although the hardness values of 1600 samples are lower, the wear resistance is better than 1500 samples. Because the flexural strengths of these 1500 samples are higher. So, we understand that the flexural strength played a decisive role in the wear properties of these mullite-added samples.

Although adhesive type wear was observed in the samples in general, it was observed that with the increase in the wear time in some samples, cracks occur on the worn surface and very small pieces break off and cause abrasive wear too.

The phase changes in the sample structure depending on the sintering temperature and time of MgZ0M and MgZ10M samples were analyzed and the basic phases that emerged in the structure were shown in Figure 5 and Figure 6.

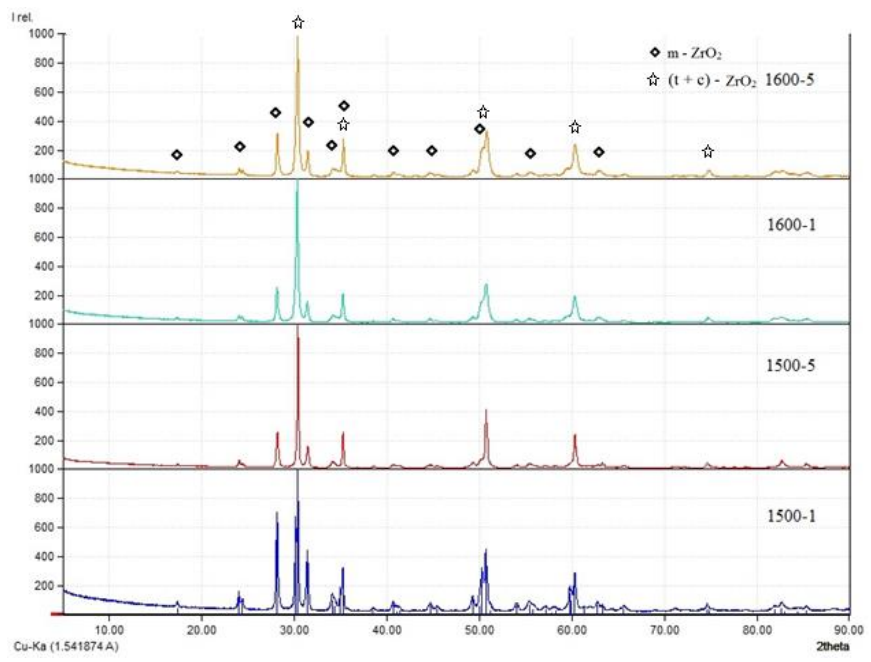

Figure 5. XRD patterns of MgZOM samples

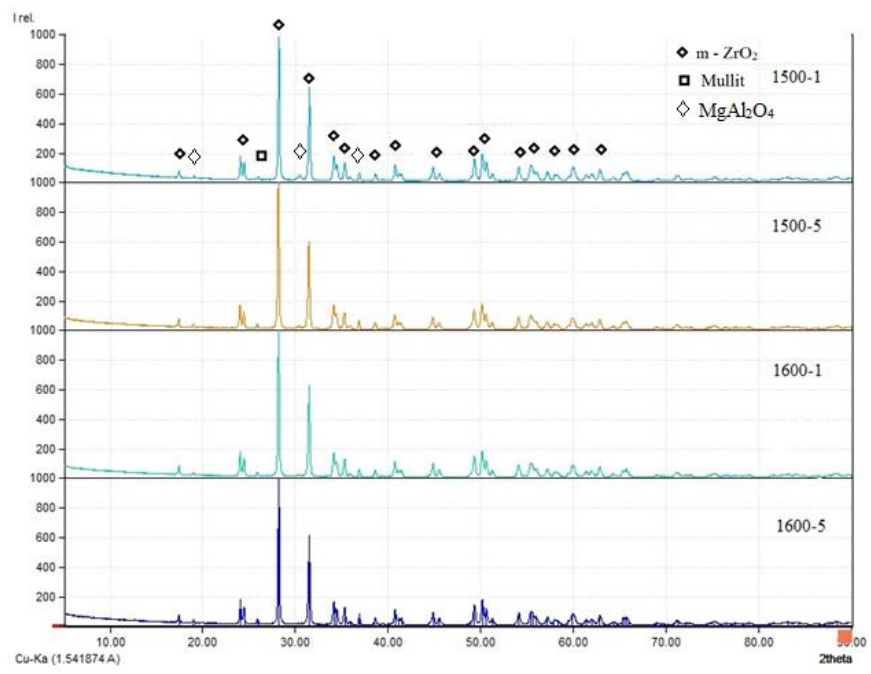

Figure 6. XRD patterns of MgZ10M samples
The microstructure image of MgZ00M16005 and MgZ10M16005 samples is given in Figure 7.
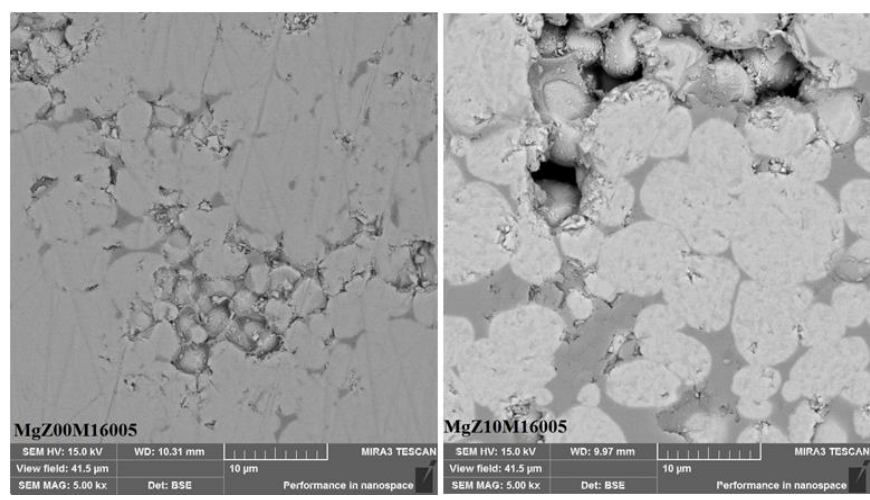

Figure 7. SEM images of MgZ00M16005 and MgZ10M16005 samples

Elemental analyzes of MgZ00M16005 and MgZ10M16005 samples with EDS are given in Figure 8 and Figure 9.

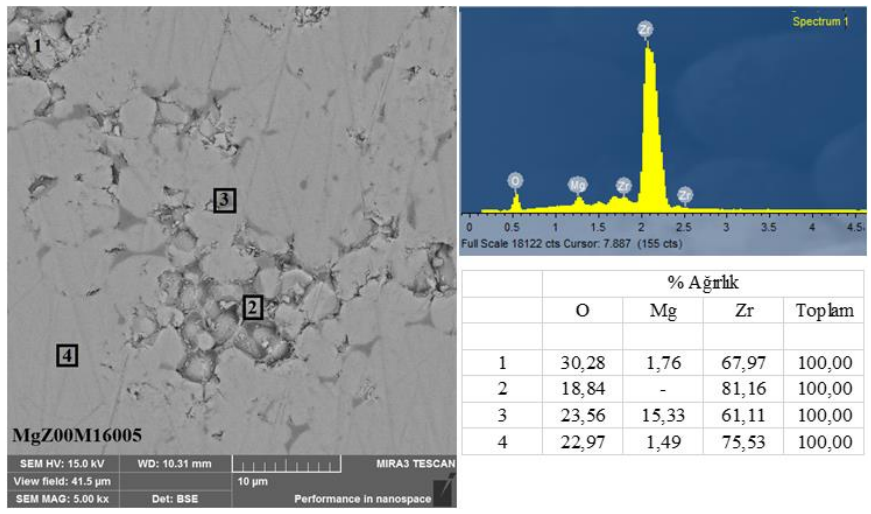

Figure 8. EDS analyses of MgZ00M16005 samples

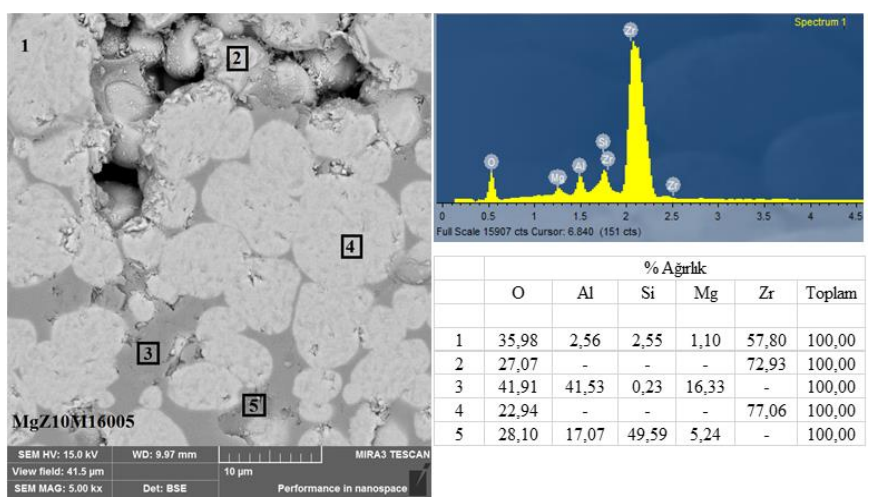

Figure 9. EDS analyses of MgZ10M16005 samples

Galusek et al [25] produced Mg-PSZ (3,5 wt $\% \mathrm{MgO}$ ) samples at $1400-1600{ }^{\circ} \mathrm{C}$ sintering temperatures with an hour sintering time using dry press and isostatic press. They reported that bending strength and fracture toughness values of 1500 samples were highest. Also, they remarked that from 1400 to 1600 sintering temperatures, the $\mathrm{c}-\mathrm{ZrO}_{2}$ phase in the structure increased and the $\mathrm{m}-\mathrm{ZrO}_{2}$ phase decreased. In addition, they specified that the samples contain large $\mathrm{c}-\mathrm{ZrO}_{2}$ grains and $\mathrm{m}-\mathrm{ZrO}_{2}$ grain boundary precipitates. It has been stated that flexural strength is 
related to fracture toughness as well as the size of large defects in the matrix.

Wang et al [26] produced $10 \mathrm{~mol} \% \mathrm{MgO}-90 \mathrm{~mol} \% \mathrm{ZrO}_{2}$ composites at $1370-1610{ }^{\circ} \mathrm{C}$ sintering temperatures for an hour and obtained the highest density value and hardness value at 1530 ${ }^{\circ} \mathrm{C}$ temperature. They stated that there was completely $\mathrm{c}-\mathrm{ZrO}_{2}$ phase in the structure at $1610{ }^{\circ} \mathrm{C}$, and the density and hardness decreased due to porosity and grain coarsening.

Similar to the work of Galusek et al and Wang et al, in our mullite-free samples from the XRD patterns given in Figure 5, it is seen that the $\mathrm{c}-\mathrm{ZrO}_{2}$ phase increased with increasing temperature and time. But in 16005 samples, the $\mathrm{m}-\mathrm{ZrO}_{2}$ phase increased in the structure again. Since the increase in $\mathrm{c}-\mathrm{ZrO}_{2}$ phase decreases the $\mathrm{t}-\mathrm{ZrO}_{2}$ phase, the bending strength decreased. In addition, the lowest bending strength was observed in 1600-5 samples, since the flexural strength would decrease due to the increase of the $\mathrm{m}-\mathrm{ZrO}_{2}$ phase and grain growth. The hardness value also decreased with the increase of the $\mathrm{m}-\mathrm{ZrO}_{2}$ phase.

Chandra et al [27] produced 2.5-10 wt $\% \mathrm{MgO}$ added mullitezirconia composite specimens at $1450-1550{ }^{\circ} \mathrm{C}$ sintering temperatures for 3-5 hours. They stated that as the temperature and time increased, the mullite ratio in the structure increased and the properties improved accordingly. In addition, it was stated that glassy phases such as spinel $\left(\mathrm{MgAl}_{2} \mathrm{O}_{4}\right)$ were formed in the structure, and these phases decreased with increasing temperature and time.

Haldar [28] produced $4-8 \mathrm{~mol} \% \mathrm{MgO}$ added mullitezirconia ceramics at $1500-1600{ }^{\circ} \mathrm{C}$ sintering temperatures by 2 hours sintering time. He stated that the density and \% shrinkage values decreased from $1500{ }^{\circ} \mathrm{C}$ to $1600{ }^{\circ} \mathrm{C}$ with $\mathrm{MgO}$.

In this respect, we think that in the mullite added samples in Figure 6, mullite increased with the increase of temperature and time and provided a more homogeneous microstructure, therefore, the flexural strength of the mullite added samples increased. It is understood that the spinel phase, which is more clearly seen in the 1500-1 sample, decreased towards the 1600-5 samples and turned into other phases. We think that this is another reason for the increase in flexural strength.

The decrease of the density values in 1600 samples give results compatible with Haldar's study. The reduction in hardness and density support each other. We think that this is due to grain coarsening.

According to the EDS analyzes given in Figure 8 and Figure 9, the evaluation of the EDS analysis results on the MgZ00M16005 and MgZ10M16005 samples was made from general (1) and parts 2, 3, 4, 5. It has been observed that the results of the EDS elemental analysis made from the general field survey (1) and other parts are compatible with the contribution rates and XRD results made to the samples.

\section{Conclusions and Recommendations}

In this study, utilization of mullite in the manufacturing of magnesia doped zirconia was investigated and it has been evaluated the effect of $\mathrm{MgO}$ and mullite contribution to $\mathrm{ZrO}_{2}$ main matrix.

In MgZ0M coded samples, with increasing sintering temperature and time, generally shrinkage, experimental density, relative density and hardness values and wear resistance increased; It was observed that water absorption, porosity and three-point flexural strength values decreased. Among these samples without mullite, the hardness value and wear resistance of the 1600-5 sample decreased. Similar to the studies of Galusek et al [25] and Wang et al [26], in the XRD patterns of our mullitefree samples, the $\mathrm{c}-\mathrm{ZrO}_{2}$ phase increased with increasing sintering temperature and time. But in 1600-5 samples, the $\mathrm{m}-\mathrm{ZrO}_{2}$ phase increased again. Since the increase in $\mathrm{c}-\mathrm{ZrO}_{2}$ phase decreased the $\mathrm{t}-\mathrm{ZrO}_{2}$ phase, the flexural strength values decreased. In addition, the lowest bending strength was observed in 1600-5 samples, since the flexural strength would decrease due to the increase of the $\mathrm{m}-\mathrm{ZrO}_{2}$ phase and excessive grain coarsening. The hardness values also decreased in 1600-5 samples due to the increase in the $\mathrm{m}-\mathrm{ZrO}_{2}$ phase.

It is seen that the three - point bending strength values of MgZ10M coded mullite added samples increase with increasing sintering temperature and time, contrary to the un-doped samples, but these values are still lower than the un-doped samples. As the studies of Chandra et al [27] and Haldar [28], we think that the mullite in the structure increased with the increase of temperature and time and provided a more homogeneous microstructure, therefore the flexural strength of the mullite added samples increased. It is understood that the spinel $\left(\mathrm{MgAl}_{2} \mathrm{O}_{4}\right)$ phase, which is more clearly seen in the XRD pattern of the 1500-1 sample, decreased towards the 1600-5 samples and turned into other phases. We think this is another reason for the increase in flexural strength.

The wear volume values of the samples with mullite additives are higher than the samples without additives; therefore, it is understood that the mullite additive affects these samples negatively and reduces the wear resistance. In addition, although the hardness values of the mullite added 1600 samples were lower, the abrasion resistance was better than the mullite added 1500 samples since their bending strength was higher and the bending strength played a decisive role in the wear properties of these samples. While shrinkage, experimental density, relative density and hardness values increased in mullite added 1500 samples; In 1600 samples, these values decreased in agreement with Haldar's [28] study. The reduction in hardness and density support each other. We think that this is due to grain coarsening.

While $\mathrm{m}-\mathrm{ZrO}_{2}, \mathrm{t}-\mathrm{ZrO}_{2}$ and $\mathrm{c}-\mathrm{ZrO}_{2}$ phases were detected in mullite-free samples; Mullite, $\mathrm{m}-\mathrm{ZrO}_{2}$ and spinel phases were detected in the mullite doped samples.

\section{Acknowledge}

This work is supported by the Scientific Research Project Fund of Sivas Cumhuriyet University under the project number M-767. Authors would like to acknowledge Scientific Research Project Fund of Sivas Cumhuriyet University.

\section{References}

[1] Boyraz, T. (2008). An investigation on physical and electrical properties of $\mathrm{CaO} / \mathrm{MgO}$-stabilized zirconia ceramics formed with different methods. Istanbul Technical University / Graduate School of Natural and Applied Sciences, (Doctoral dissertation). 150p.

[2] Pekdemir, A.D. (2018). Preparation and characterization of boron carbide at low-temperature from boric acid and polyols. Ankara University / Graduate School of Natural and Applied Sciences, (Doctoral dissertation). 178p 
[3] Ceylan, A. (2006). The production of functionally graded SiAlON ceramics by tape casting method. Anadolu University / Graduate School of Natural and Applied Sciences, (Doctoral dissertation). 204p.

[4] Abi, C.B. (2009). An investigation on fracture toughness of traditional and technical ceramics. Afyon Kocatepe University / Graduate School of Natural and Applied Sciences, (Doctoral dissertation). 194p.

[5] Hafızoğlu M. A., Boyraz, T. and Akkuş, A. (2021). Fabrication, characterization and wear properties of mullite reinforced silica-doped zirconia ceramic composites. 4. International Conference on Materials Science, Mechanical and Automotive Engineerings and Technology (IMSMATEC'21).

[6] Hafızoğlu M. A., Akkuş, A. and Boyraz, T. (2021). Fabrication, characterization and wear properties of mullite reinforced $\mathrm{A} 12 \mathrm{O} 3$-doped $\mathrm{ZrO} 2$ ceramic composites. Global Conference on Engineering Research (GLOBCER'21).

[7] Hafizoğlu M. A., Boyraz, T. and Akkuş, A. (2021). Fabrication and characterization of mullite reinforced $\mathrm{TiO} 2$ added $\mathrm{ZrO} 2$ ceramics. International Joint Science Congress of Materials and Polymers (ISCMP'21).

[8] Cutler, R. A., Reynolds, J. R. and Jones, A. (1992). Sintering and characterization of polycrystalline monoclinic, tetragonal, and cubic zirconia. Journal of the American Ceramic Society, 75(8), 2173-2183.

[9] Boyacioğlu, T. (2007). Improvement of room temperature mechanical properties of various amount of metal oxide doping cubic zirconia (c-ZrO2) used as electrolyte material for solid oxide fuel cells. Gazi University / Graduate School of Natural and Applied Sciences, (Master's thesis). 123p.

[10] Boyraz, T. (1998). Dental porcelain powders. Sakarya University / Graduate School of Natural and Applied Sciences, (Master's thesis). 131p.

[11] Liu, P. F., Li, Z., Xiao, P. et al. (2018). Microstructure and mechanical properties of in-situ grown mullite toughened $3 \mathrm{Y}$ TZP zirconia ceramics fabricated by gelcasting. Ceramics International, 44(2), 1394-1403.

[12] Eichler, J., Rödel, J. et al. (2007). Effect of grain size on mechanical properties of submicrometer 3Y-TZP: fracture strength and hydrothermal degradation. Journal of the American Ceramic Society, 90(9), 2830-2836.

[13] Sun, J., Gao, L., Iwasa, M., Nakayama, T. and Niihara, K. (2005). Failure investigation of carbon nanotube/3Y-TZP nanocomposites. Ceramics International, 31(8), 1131-1134.

[14] El Ouatib, R., Guillemet, S., Durand, B. et al. (2005). Reactivity of aluminum sulfate and silica in molten alkalimetal sulfates in order to prepare mullite. Journal of the European Ceramic Society, 25(1), 73-80.

[15] Kucuk, I. and Boyraz, T. (2019). Structural and mechanical characterization of mullite and aluminium titanate reinforced yttria stabilized zirconia ceramic composites. Journal of Ceramic Processing Research, 20(1), 73-79.

[16] Kumar, P., Nath, M. et al. (2015). Enhancement of thermal shock resistance of reaction sintered mullite-zirconia composites in the presence of lanthanum oxide. Materials Characterization, 101, 34-39.

[17] Roy, J., Das, S. and Maitra, S. (2015). Solgel-processed mullite coating - a review. International Journal of Applied Ceramic Technology, 12, E71-E77.

[18] Denry, I. and Kelly, J. R. (2008). State of the art of zirconia for dental applications. Dental materials, 24(3), 299-307.
[19] Çitak, E. and Boyraz, T. (2014). Microstructural characterization and thermal properties of aluminium titanate/YSZ Ceramics. Acta Physica Polonica A, 125(2), 465-468.

[20] Önen, U. and Boyraz, T. (2014). Microstructural characterization and thermal properties of aluminium titanate/spinel ceramic matrix composites. Acta Phys. Pol. A, 125(2), 488-490.

[21] Sacli, M., Onen, U. and Boyraz, T. (2015). Microstructural characterization and thermal properties of aluminium titanate/porcelain ceramic matrix composites. Acta Physica Polonica A, 127(4), 1133-1135.

[22] Boyraz, T. and Akkuş, A. (2021). Investigation of wear properties of mullite and aluminium titanate added porcelain ceramics, Journal of Ceramic Processing Research. Vol. 22, No. 2, pp. 226-231.

[23] Akkus, A. and Boyraz, T. (2018). Investigation of wear properties of $\mathrm{CaO}, \mathrm{MgO}$ added stabilized zirconia ceramics produced by different pressing methods. J Ceram Process Res, 19(3), 249-52.

[24] Kucuk, I., Boyraz, T. et al. (2018). Thermomechanical properties of aluminium titanate (A12TiO5)-reinforced forsterite $(\mathrm{Mg} 2 \mathrm{SiO} 4)$ ceramic composites. Ceramics International, 44(7), 8277-8282.

[25] Galusek, D., Znášik, P., \& Majling, J. (1999). The influence of cold isostatic pressing on compaction and properties of Mg-PSZ ceramics. Journal of materials science letters, 18(16), 1347-1351.

[26] Wang, J., Chu, D., Ma, H., Fang, S., Chen, Q., Liu, B., ... \& Jia, X. (2021). Effect of sintering temperature on phase transformation behavior and hardness of high-pressure hightemperature sintered $10 \quad \mathrm{~mol} \%$ Mg-PSZ. Ceramics International, 47(11), 15180-15185.

[27] Chandra, D., Das, G., \& Maitra, S. (2015). Comparison of the Role of $\mathrm{M} g \mathrm{O}$ and $\mathrm{C} \mathrm{a} \mathrm{O}$ Additives on the Microstructures of Reaction-Sintered Zirconia-Mullite Composite. International Journal of Applied Ceramic Technology, 12(4), 771-782.

[28] Haldar, M. K. (2003). Effect of magnesia additions on the properties of zirconia-mullite composites derived from sillimanite beach sand. Ceramics international, 29(5), 573581. 